\title{
Mais um relato de experiências na educação superior durante a pandemia da COVID-19?
}

Giselle Martins dos Santos Ferreira ${ }^{1}$

\section{RESUMO}

O presente texto consiste em um relato de experiências acerca da Educação Superior durante a pandemia de Covid-19, reunindo e adaptando textos publicados no blog acadêmico da autora, um espaço digital direcionado a professores e estudantes interessados em abordagens críticas à tecnologia educacional. Este trabalho também inclui recomendações de leitura, bem como traz apêndices com exemplos do material didático-pedagógico produzido pela autora.

Palavras-chave: Educação Superior durante a pandemia de Covid-19. Ensino Remoto Emergencial. Ação Pedagógica. 
Yet another account of experiences in education during the COVID-19 pandemic?

\section{ABSTRACT}

This article consists in an account of experiences in higher education during the Covid-19 pandemic. The text brings together and adapts articles published on the author's academic blog, which is aimed at teachers and students interested in critical approaches to educational technology. The article includes reading suggestions and appendices with teaching material produced by the author.

Keywords: Higher Education during the Covid-19 pandemic. Emergency Remote Teaching. Pedagogy. 
Ofereço aqui uma síntese que reúne e adapta uma série de postagens que venho compartilhando em meu blog acadêmico desde o primeiro período da quarentena no Rio de Janeiro, decretada em meados de março de 2020. Sinto-me honrada e muito grata pelo convite para publicar esta síntese de material no dossiê da revista Em Rede. Espero conseguir apresentar aqui, de forma coerente, algumas das reflexões que venho fazendo ao longo desse período tão difícil que estamos vivendo.

O presente texto, portanto, não é, exatamente, um artigo acadêmico, mas sim um relato de uma experiência em andamento, escrito em linguagem relativamente informal. Ainda que a experiência e reflexões sejam pessoais, elas parecem ecoar junto a outros que me tem dado retorno por ocasião das publicações de postagens: colegas, alunos e ex-alunos que, assim como eu, valorizam sobremaneira a profissão docente. 0 artigo tem, de forma geral, um caráter de position piece, ou seja, um texto de posicionamento do autor, articulando observações, reflexões e questões a conceitos e ideias de uma literatura acadêmica relativamente vasta, porém, aqui representada a partir de uma pequena seleção de textos.

Penso ser essencial esclarecer que, de modo geral, utilizo meu blog para compartilhar ideias, reflexões, recomendações de leituras e eventos, resenhas curtas, mapas mentais, enfim, recursos que, acredito, possam ser úteis a alunos e colegas dentro e fora da instituição em que atuo. Nesse sentido, considero-me uma digital scholar (WELLER, 2011): uma professora pesquisadora, engajada na utilização de meios digitais no ensino, na pesquisa e, em particular, na comunicação junto a diferentes comunidades das quais faz parte - e sempre com um olhar particularmente atento aos professores e pesquisadores em formação. Talvez o mais importante para mim seja que a escrita no blog me ajuda a organizar os pensamentos e tem, de experiências anteriores com outros blogs e sites que mantive, mostrado-se bastante inspiradora, de fato, profícua no sentido de oportunizar novos contatos, relações de trabalho e escritas mais formais. Venho de muitos anos de atuação em uma cultura de trabalho em equipe, ou team teaching, autoria coletiva e compartilhamento aberto, e sempre me será bastante estranha a ideia de que qualquer texto seja estanque, imutável, irrepreensível: para mim, todo texto é situado, polifônico e inacabado.

0 artigo retoma ideias compartilhadas em postagens feitas ao longo de pouco mais de um ano, tempo no qual a educação conduziu o que chamei de "virada on-line" na sequência do fechamento gradativo das instituições de ensino do país. Com tantas "viradas" já pensadas nas humanidades - linguística, retórica, material etc. -, a esta altura já não sei dizer com certeza como a expressão apareceu naquela primeira postagem de março do ano passado. Há um ou dois equivalentes em inglês - online pivot e online turn -, bem como menções em outros textos nacionais, o que me sugere uma forma de sincronicidade. De qualquer modo, acredito que o termo expressa a urgência da manobra que tivemos que efetuar; então, tomemos esse sentimento para início de conversa. 

HUMANOS

Minha primeira reação a essa "virada" foi de uma certa descrença. Tive, na época, e continuo tendo muitas conversas com colegas e amigos - meus amigos mais próximos são, também, professores, e sou muito grata por essa nossa pequena rede de sanidade -, e dizer que "estamos todos no mesmo barco" simplesmente nunca foi e continua não sendo realista. Estamos diante de um cenário anteriormente inimaginável. As incertezas são múltiplas, e as tarefas diárias multiplicaram-se. Não estamos em casa sem trabalhar ou nos recusando a trabalhar, como dizem os desinformados e oportunistas. Pelo contrário: temos muito mais a fazer a respeito de tudo que já tínhamos que cuidar antes da chegada do atual tsunami. Porém, nada disso se dá da mesma forma para todos nós. E nesse "todos nós" quero incluir, em particular, os estudantes, pois foi exatamente pensando neles que comecei minhas reflexões por escrito.

Nesse espírito, acho importante destacar logo de saída algo que os estudiosos da Educação a Distância (EaD) já sabem há muito: que a ideia da "aula", em especial, da aula eminentemente expositiva, não é diretamente transferível para contextos de ensino e aprendizagem não presenciais. Os suportes tecnológicos que temos, de modo geral, criam e operam em tempos e espaços diferentes, demandando sujeitos - professores e alunos -; outros, reconfigurados a partir de possibilidades de interação e mediação diferentes daquelas que podemos concretizar com a presença do corpo. Essa reconfiguração demanda reflexão, adaptação e mudança, ou seja, aprendizagem.

Mesmo na Open University, onde vivi, entre o final da década de 1990 e meados da década de 2000, uma "virada on-line" que diminuiu drasticamente o contato presencial entre tutores e alunos, inclusive nas tradicionais escolas de verão adoradas pelos estudantes, ficou claro que a presença física em locais específicos - por exemplo, laboratórios ou salas de aula, no caso da formação de professores - não poderia ser abandonada. Há quem pense que é apenas uma questão de termos artefatos mais sofisticados à nossa disposição, artefatos que ofereçam simulações mais realistas de coisas do mundo e de nós mesmos, avatares mais "realistas" para sustentarem formas de presença mais consistentes no dito "ciberespaço". Não partilho do otimismo dos tecnólogos quanto a essas possibilidades, pois creio, como sugere Edgar Gómez Cruz (2021), que o ciberespaço nada mais é do que "uma alucinação consensual acadêmica" veja recomendações de leitura. Lamentavelmente - ou não, deixo ao leitor a opção de fazer seu próprio juízo de valor -, penso que, na verdade, há muito que simplesmente não sabemos sobre a aprendizagem, com ou sem a mediação de artefatos digitais.

Para ser mais pragmática, gostaria de lembrar que a EaD tem um aspecto básico: em qualquer modelo - e é sempre importante ressaltar que há muitos modelos -, a etapa de planejamento e produção - de planos e ações pedagógicas, recursos, etc. - é mais longa e detalhada do que seria o usual na Educação Presencial. Crucialmente, não me parece ser uma modalidade para qualquer estudante: a literatura da área é repleta de conceitos, como autonomia, autodirecionamento, organização, motivação, enfim, uma variedade de ideias problemáticas e discutíveis, mas que formam a base das concepções do "estudante" ao qual a EaD tem sido dirigida há décadas, em muitos casos, com bastante sucesso. 
Tenho prestado bastante atenção aos relatos de alunos e, dentro da minha própria casa, venho observando com cuidado minha filha, também estudante universitária, a passar horas diariamente diante da tela do computador, oscilando entre uma forma de desespero - aula após aula no Zoom, além de leituras longas, listas de exercícios, enfim, excesso de demandas com prazos inexequíveis na melhor das épocas - e total desânimo no fim de dias que se estendem até bem tarde. E aqui temos uma boa conexão à internet, múltiplos espaços para nos movimentarmos ao longo do dia, silêncio e tranquilidade - além de uma despensa bem provida -, ou seja, condições que não são universais. Isso quer dizer: não se trata apenas de questões de exclusão digital compreendida como falta de acesso a bens materiais - especificamente computadores e acesso à internet -, mas, sim, de reflexos mais profundos de grandes desigualdades sociais.

Além disso, para minha filha como para a maioria dos estudantes, quer sejam mais ou menos privilegiados, a socialização tomou, por força das circunstâncias, outras formas, inclusive os sítios riquíssimos de aprendizagem entre pares também são outros e não mais a cantina, a biblioteca ou o boteco da esquina. Foram-se as horas gastas todos os dias no transporte público, horas que, mesmo "no aperto" de um carro de metrô, podiam ser desfrutadas com leituras leves no celular, conversas com amigos ou, simplesmente, devaneios. E se esse tempo agora é vivido em casa, não o é de forma ociosa, pois o estudante também foi convocado a participar mais, em um dia a dia inteiramente diferente do que todos imaginávamos viver a esta altura. Somemos a isso a incerteza criada pela forma discutível na qual a pandemia tem sido tratada em nível de política desde o início, com especialistas vistos como cassandras que exageravam o alcance do problema e suas possíveis repercussões ao longo de um tempo bem mais longo do que as poucas semanas de lockdown decretado de modo desigual país afora.

Pois a "virada on-line" começou no Brasil um pouco depois da Europa e EUA, acompanhando a chegada - ou identificação? - de casos da Covid-19 no país, mas eu já estava a seguir notícias em redes, jornais e blogs especializados internacionais. No próprio Facebook, uma das vozes mais sensatas que conheço em minha área de pesquisa, a estadunidense Audrey Watters - veja a bibliografia comentada -, resumiu no início de março de 2020 a minha própria reação inicial à adoção de plataformas e ferramentas digitais a partir de "abordagens pedagógicas a distância" com crianças em idade escolar: que ninguém morreria se não aprendesse a tabuada de sete naquele ano. No caso da minha filha, um dos desafios iniciais era aprender a conjugar vários verbos em latim, que ela conseguiu, por fim, superar, mas não sem muito suor e algumas lágrimas.

Contudo, a situação se prolongou além do que inicialmente se esperava, e, agora, mais do que há um ano, é inviável pensar na suspensão completa de atividades, não apenas em uma perspectiva institucional - pensando aqui, sobretudo, em instituições privadas -, mas, também e de modo crucial -, humana. A distância facilmente transforma pessoas em números registrados em planilhas de apoio a falsas dicotomias - salvar vidas ou salvar a economia? -; no entanto, professores tendem a enxergar pessoas: alunos com diferentes necessidades, demandas, questões e, em alguns casos, problemas previamente existentes - por exemplo, ansiedade, doença do pânico, depressão, enfim, a lista é longa. Continuar o contato com colegas e professores pode ter se tornado, para alguns - ou para muitos? Quem sabe? -, uma âncora em 
meio à incerteza, oferecendo referências para a construção emergencial de novos cotidianos. A questão aqui, porém, é o que fazer para que essa âncora não se torne mais um fardo em meio a esses cotidianos provisórios que tivemos que inventar.

Instituições diferentes adotaram formas diferentes para descrever o que então passaram a fazer: "Educação não presencial", "Educação on-line", "Educação digital" e o mais comum "Ensino Remoto Emergencial". Não é fácil escolhermos uma denominação para o que estamos fazendo, também porque há implicações comunicacionais, uma vez que a EaD, em geral, não tem a melhor das reputações no país, e nomes diferentes terão maior ou menor apelo, em particular, para quem financia a experiência - por exemplo, pais e responsáveis.

De qualquer modo, ao longo do ano, os rótulos foram se multiplicando, como o foram os debates e disputas territoriais acadêmicas; mas uma coisa me pareceu certa no início: tudo que podíamos fazer seriam ações emergenciais, tentativas e, para muitos, inteiramente novas e experimentais. Não sabíamos o que viria, entretanto sabíamos o que se apresentava: todos queríamos a sobrevivência de nossas respectivas instituições, porém ninguém queria adoecer ou, sobretudo, adoecer os estudantes.

Não faço aqui uma crítica às ações de colegas ou das determinações postas por instituições, todos preocupados com a situação a partir de suas perspectivas próprias. Para mim, a profissão docente é uma das profissões do cuidado com o outro e, assim, sob pressão e em destaque no momento. Não sei o quão generalizada foi ou continua a ser a situação de overload dos estudantes; mas, pelo que tenho visto com colegas e amigos também professores, permanece sintomático, ao menos entre nós, o meme que uma aluna me enviou em final de março - Figura 1.

\section{Figura 1: meme - EAD}

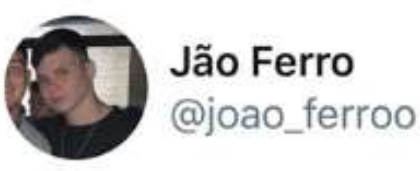

\section{EAD - Estresse A Distância}

\section{$12: 03 \cdot 24 / 03 / 2020 \cdot$ Twitter for iPhone}

\section{Fonte: Arquivo pessoal da autora.}

O cenário mudou desde março do ano passado: estamos em meio a um processo - lento de vacinação da população e ainda vivemos uma considerável insegurança em relação ao que virá em seguida. Assim, creio que ainda vale o convite que deixei naquele momento: que pensemos cuidadosamente sobre o que estamos a fazer, ouvindo as vozes dos nossos estudantes e a eles explicando, nos limites do razoável, perspectivas que eles próprios não podem ter. Se a proverbial corrente é tão forte quanto seu elo mais fraco, focalizar meramente em tecnologias e em "transposição para o on-line" é uma armadilha que precisamos evitar para permanecermos humanos. Adiciono aqui que precisamos também ouvir nossas próprias vozes e respeitar nossos 
próprios limites: a situação não é um "novo normal", mas constitui-se, talvez, em uma oportunidade para revermos nossas formas de ser, de existir e de agir profissionalmente. Para isso, porém, precisamos refletir sobre o que temos feito, assunto do qual trato na próxima seção.

\section{O DIA DEPOIS DE AMANHÃ VIRÁ, MAS O QUE ESTAMOS APRENDENDO HOJE?}

Para quem gosta de cinema, parte do título desta seção remeterá a cenas de um planeta Terra arrasado por uma catástrofe ambiental. Nesse cenário, ironicamente, um hemisfério Norte congelado encontra sua salvação em um hemisfério Sul quente, acolhedor. Talvez esteja aí uma representação caricata do que estamos a viver na educação em geral: uma forma de refúgio em práticas de uma modalidade que opera sem que professores e alunos estejam fisicamente juntos e que nem sempre é vista com bons olhos.

Um outro cenário apocalíptico é o de 2012. Nesse filme, o drama também se desenrola a partir de uma crise ambiental; nesse caso, havia um projeto secreto multinacional que construíra embarcações destinadas a preservar o melhor da humanidade quando a tragédia finalmente se concretizasse. Obras de arte, livros e pessoas específicas - cientistas, artistas e líderes políticos haviam sido selecionados para embarcar quando chegasse o inevitável momento de destruição. Obviamente, não haveria arcas para todos, mas o filme nada mostra sobre as considerações envolvidas nas "escolhas de Sofia" prévias: simplesmente seguem-se - não sem percalços obviamente - caminhos já traçados, como se tem feito agora em relação às escolhas que os profissionais da saúde precisam fazer em contextos de falta dos recursos necessários para o tratamento de casos graves da COVID-19.

Na docência, não lidamos com escolhas de vida ou morte, então não temos o mesmo tipo de urgência, mas estamos também diante de escolhas, dilemas e paradoxos. São escolhas difíceis, pois, no dia depois do amanhã ainda incerto, que será o final desta pandemia, creio, não seremos os mesmos, nem habitaremos o mesmo mundo de antes. Na verdade, como já disse acima, meu primeiro pensamento ao receber a circular de fechamento do campus em final de março foi que não estaríamos todos no mesmo barco, para começar. Em 2012, não havia arcas suficientes para toda a humanidade, e esse é o caso da educação durante a quarentena, infelizmente. E os que são deixados de fora não são apenas os despossuídos, pois uma gama de problemas anteriores parece ter sido exacerbada, incluindo questões de saúde mental que se somam a outros problemas trazidos pelo distanciamento social. Nesse sentido, podemos também causar sofrimento com nossas escolhas e ações.

Para mim, a situação ilumina um aspecto talvez negligenciado de nossa profissão, já mencionado acima: como formadores, somos também, de alguma forma, cuidadores. Juntos, formamos engenheiros, cientistas, professores e muitos outros profissionais. Contudo, uma vez que ser profissional é uma face importante de ser no mundo, contribuímos fortemente, na realidade, para formar pessoas. Foi pensando assim que as minhas primeiras preocupações diante do que se apresentava em meados de março convergiram em torno da necessidade de encontrarmos formas de permanecermos humanos, dosando as demandas que iríamos impor a nossos alunos e a nós mesmos. 
A pandemia acabará, mas o que será, como será, quando será são assuntos já em discussão por colegas bem mais afeitos à futurologia do que eu. Porém, os cenários que eles têm desenhado, em geral, não são necessariamente animadores, como não são animadores os cenários de uma educação mercantilizada, uma realidade que mobiliza grandes números de atores e grandes cifras. Nesse contexto, temos também problemas cotidianos imediatos e prementes a tratar. Mantendo uma dose de otimismo, penso como Neil Selwyn, um sociólogo inglês muito conhecido na minha área de pesquisa, que é bastante enfático ao falar sobre a importância das escolhas que os professores fazem no agora, como contribuições que podem, sim, ajudar a moldar o depois da educação.

Selwyn enfatiza, sempre, o papel da desconfiança como uma forma inicial de resistência (SELWYN, 2014). O pesquisador vem falando, há mais de duas décadas, sobre a necessidade de desconfiarmos de certas premissas que têm sido tomadas como verdades na educação contemporânea. Por exemplo, somos constantemente convocados a inovar - ou morrer? -, e a inovação na educação toma a forma de uma mudança de centro das ações pedagógicas - do professor para o aluno - e, consequentemente, de método - e fala-se muito de metodologias ativas - (PISCHETOLA; MIRANDA, 2019), bem como de "ferramentas" - "Usem tecnologias digitais!", dizem-nos. Impera o "solucionismo tecnológico" (MOROZOV, 2013): a ideia de que artefatos tecnológicos seriam a solução dos problemas de uma educação quebrada.

O proselitismo do novo que caracteriza essa convocação à inovação não é, obviamente, uma peculiaridade da educação, mas temos empresas, grandes e não tão grandes, e seus evangelistas a nos oferecer produtos que, dizem, irão melhorar nossa performance. Dizem-nos que seus produtos nos tornarão professores não apenas mais eficazes, mas, de modo crucial, mais eficientes. Contudo, no cenário que desenham, professores figuram, com frequência, como peças imperfeitas e substituíveis. Existimos, cada vez mais fortemente - inclusive nos discursos das políticas públicas - como parte de um maquinário em transformação ou progresso rumo a maiores eficiências.

Nesse contexto, já era grande a minha preocupação com a fragmentação e a desumanização da nossa profissão bem antes de entrarmos na emergência atual. Pois bem, exatamente por força das circunstâncias, tivemos que inovar no sentido de nos adaptarmos a uma realidade nova, e os artefatos digitais têm sido realmente essenciais para podermos continuar a agir e interagir. Porém, para muitos de nós, essa é a primeira experiência com mídias digitais na educação e com a Educação não presencial. E agora, fala-se de um futuro da educação baseado em um "Ensino Híbrido" pós-pandemia. Não sabemos o que a semana que vem trará, muito menos o próximo semestre, e exatamente por isso podemos pensar em planejamento também como forma de resistência.

Nesse sentido, a questão geral que perpassa essa seção é a seguinte: o que estamos aprendendo com as ações - talvez não mais tão emergenciais após mais de um ano - que temos conduzido? A partir dessa questão, proponho três desdobramentos, dos quais tratarei a seguir em termos de alguns outros desdobramentos possíveis, ou seja, mais perguntas: o que estamos aprendendo sobre as tecnologias que estamos usando? O que estamos aprendendo sobre nós mesmos como professores? O que estamos aprendendo sobre o nosso público? 


\subsection{Sobre as tecnologias}

Os artefatos à nossa disposição modificam profundamente a experiência da socialização e da interação. Por exemplo, o Zoom, utilizado em minha instituição, tem sido ótimo, de algumas formas, mas há diferenças significativas em relação à interação presencial - inclusive já há pesquisas sobre a forma de "exaustão cognitiva" associada ao uso excessivo de videoconferência (FAUVILLE et al., 2021). O meme mostrado na Figura 2 reverbera algumas percepções correntes de forma bem-humorada.

Figura 2: meme - "Finalmente descobri o que as reuniões no Zoom me lembram"

\section{Finally understood what zoom meetings remind me of.}

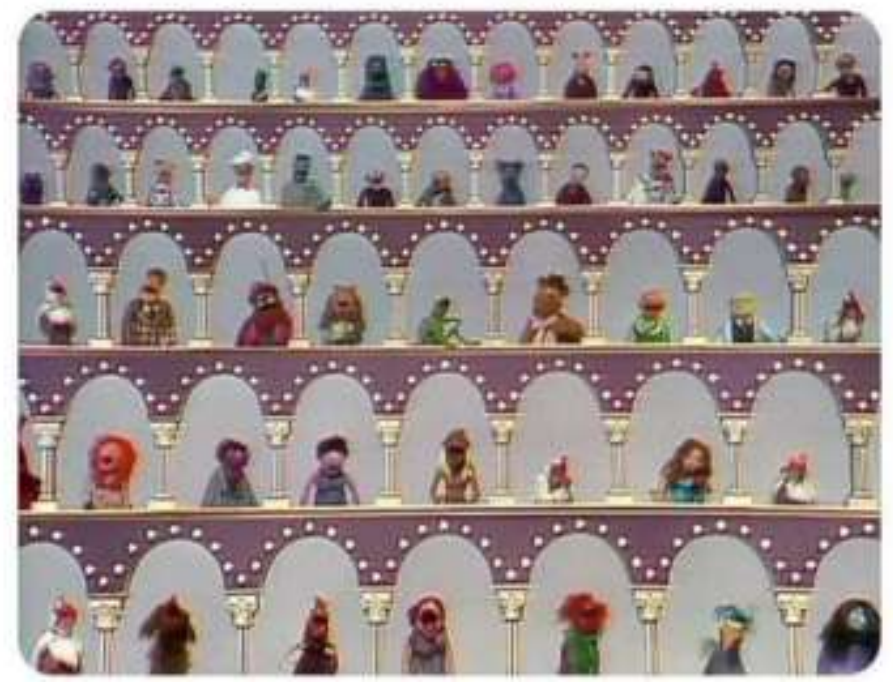

\section{Fonte: Arquivo pessoal da autora.}

Tenho usado a plataforma semanalmente, com o tempo um pouco reduzido, com as minhas turmas de pós e meu grupo de pesquisa, mas, na graduação, fui adaptando meu uso ao longo dos semestres, pois as turmas tendem a ser bem maiores. O retorno que recebo deles é misto: os comentários menos animadores têm vindo de alunos com problemas de conexão à internet ou que acham que a videoconferência invade a sua privacidade. Eles me contam sobre pequenos atos de "desobediência civil" que me fazem rir, como o meme mostrado na Figura 3. Creio, contudo, que temos aqui questões muito importantes a serem pensadas, relacionadas ao papel da dialogia no ensino-aprendizagem, questões que - é preciso ressaltar - não são relevantes exclusivamente a contextos de aprendizagem on-line. 
Figura 3: meme - "Hoje, um dos meus alunos do $4^{\circ}$ ano se renomeou 'Reconectando..." em nossa chamada de Zoom e fingiu que estava com problemas na internet para evitar participar na aula"

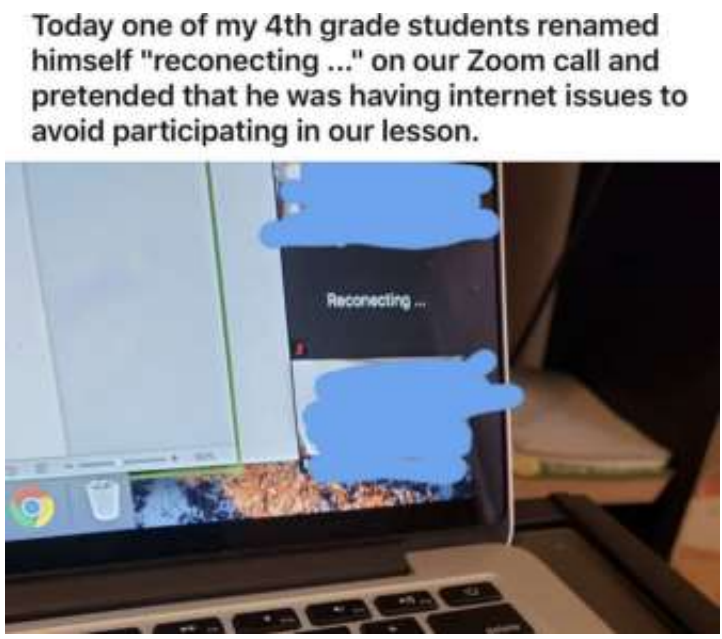

Fonte: Arquivo pessoal da autora.

E-mail e fóruns de Web podem ser bastante produtivos em algumas situações; de fato, as mídias assíncronas tendem a ser a primeira escolha na EaD, que precisa operar a partir de requisitos tecnológicos mínimos para cumprir demandas de inclusão. A pesquisa na área de Comunicação Mediada por Computador (CMC) já vem da década de 1980, e há relatos que defendem ideias como "massa crítica" - número mínimo de participantes para que haja interação - e "teto" - número máximo de participantes para que não haja caos - para considerarmos. Fazer escolhas aqui significa aprendizagem para nós também, pois, para além de termos que vencer questões instrumentais - como fazer o quê -, também temos que nos adaptar aos tipos de conversas possíveis por meio das mídias que usamos. E mais: precisamos ensinar os alunos a conversar dentro dessas novas possibilidades - ou restrições. Nesse sentido, acho relevante pensarmos sobre a constituição de diferentes formas de presença e distância no ensinoaprendizagem (VALLE; BOHADANA, 2013), pois enormes distâncias podem existir em sala, assim como diferentes modos de presença podem ser construídos por meio de ambientes puramente textuais. Essas não são questões triviais.

\subsection{Sobre nós mesmos}

Como professores, criamos programas ou planos de disciplinas a partir de ementas integradas em matrizes curriculares. Nossa atuação segue diretrizes e concepções consistentes com as demandas de nossas respectivas áreas; mas isso revela mais: nossas ações pedagógicas materializam nossas formas de pensar sobre o que é ensinar e revelam o que pensamos ser aprender. Em outras palavras, nossas concepções de ensinar e de aprender, com frequência tácitas, estão sempre em jogo e "à mostra", digamos, em nossas ações. 
Em nosso vernáculo docente, falamos de nossos currículos como constituídos de "conteúdos" que "expomos", "passamos" ou "transmitimos" aos alunos, que aprendem "recebendo", "absorbendo" ou "digerindo" o que lhes oferecemos. Trata-se, aqui, de metáforas muito poderosas, porém naturalizadas, ou seja, não mais pensadas como metáforas: são dispositivos que constituem bases sobre as quais construímos nossas ações (FERREIRA; LEMGRUBER, 2018; LEMGRUBER; FERREIRA, 2018). Concretizam-se na aula expositiva mais tradicional, no âmbito da hora-aula em sala, nas baterias de exercícios, nos tipos de atividades ou problemas que propomos aos alunos, enfim, em tudo que fazemos em termos de ações pedagógicas.

No momento, porém, em parte por limitações das próprias mídias que estamos usando, e, em parte por questões de ordem prática, tornou-se, para mim, um ponto para reflexão a ideia da hora-aula do presencial compreendida como aquele intervalo de tempo que passamos juntos com nossos alunos em um espaço compartilhado. Quando planejada, a EaD se concentra em estimativas das horas de estudo que o aluno precisará; no presencial, isso nos passa despercebido. Há, por esse motivo, uma preocupação constante em marcar o ritmo desse estudo com um cronograma que preveja a criação de produtos para avaliação continuada. A copresença pode tomar outras formas, por exemplo, a aula escrita de Holmberg, a teleaula, a aula gravada, tão comum nos MOOC - os Cursos On-line Abertos e Massivos de grandes instituições internacionais -, a aula dramatizada, que usa formatos do cinema e da TV, enfim, uma variedade de possibilidades (HOLMBERG, 1989; WELLER, 2020).

A questão aqui não é apenas conhecimento de estratégias didáticas. É claro que um repertório de técnicas variadas, associadas à produção com fins de acompanhamento do progresso dos alunos, pode ser muito útil: Diários de Aprendizagem - ou de bordo -, que encorajam a tomada de notas, escrita e reflexão; estudos dirigidos, que indiquem especificidades de textos - ou outros recursos - a serem tratadas; projetos; trabalhos estruturados em etapas para pequenos grupos; novidades como Webquests, jogos etc. A lista é longa e cada área já tem tanto preferências quanto práticas tradicionais, e não vejo motivo para que elas sejam simplesmente ignoradas ou consideradas "antiquadas", pois, para mim, o cerne da questão não é técnico, mas, sim, conceitual. Há questões de poder envolvidas, também, porque operamos em múltiplos contextos - áreas de conhecimento diferentes, níveis diversos de organização da instituição em que nos inserimos etc. As próprias mídias e políticas veiculam expectativas e "senso comum" sobre a educação. Enfim, acredito que a questão é de valores, premissas e crenças enraizados em história e política, não apenas nossos, mas também de nosso público.

\subsection{Sobre o nosso público}

Podemos rotular o que estamos fazendo de diferentes formas, em particular, ressaltando o caráter emergencial dos arranjos atuais. Porém, a emergência se estendeu e, como não temos condições ainda como promover a copresença física de professor e alunos - apesar das pressões -, permanece difícil escapar da ideia de que estamos, de fato, à distância. E em todos os modelos de Educação a Distância que conheço, trata-se de uma educação imaginada para um tipo específico de estudante: um adulto independente, relativamente amadurecido como aprendiz e 
intrinsicamente motivado para aprender. A EaD tem mais de um século de história, mas, apesar de toda a discussão e literatura a seu respeito, ainda há muito que não compreendemos. $\mathrm{A}$ educação em nível básico - ou compulsório -, por exemplo, figura nessa história em termos de casos extraordinários, em geral, como complemento; em alguns casos, suplemento e, raramente, como modalidade principal na formação de crianças e jovens. Como pensei logo de início, a Educação Básica me parece o desafio maior de todos.

Mesmo na Educação Superior, há dificuldades em lidar com o nosso público; no entanto, são eles - os alunos - a nossa razão de ser! Muitos de nós também estamos envolvidos em pesquisa, mas, mesmo na pesquisa, nosso papel como formadores é fundamental. Nesse sentido, uma premissa que talvez tenhamos em comum seja que não queremos "nenhum - aluno - a menos". Aqui vamos ao encontro de nossas instituições com esforços no sentido de minimizar a evasão, é claro; mas evasão é um problema complexo, e mesmo que nosso papel seja chave, nosso alcance e possibilidades de ação produtiva são limitados, então não faz sentido sermos responsabilizados por esse problema.

$\mathrm{Na}$ EaD, de forma geral, por mais que os estudantes sejam surpreendidos ao ingressar, por mais dificuldades que tenham, partimos de um acordo tácito básico sobre o modelo de ensinoaprendizagem, uma forma de "contrato". Esse modelo exige alunos minimamente dispostos a se apropriarem de sua aprendizagem. Não era esse, porém, o nosso "acordo" no início de 2020, sem contar que as expectativas de nossos alunos quanto ao seu próprio papel no processo de aprender sempre variam muito, como variam suas habilidades.

Aprecio muito ouvir relatos de colegas sobre esse assunto, e creio que há pesquisas pertinentes em andamento, mas, de minha parte, tenho observado um grande despreparo dos estudantes em termos de leitura, escrita e escuta. As expectativas que trazem sobre o que é aprender tendem a ser coloridas por suas experiências de escolarização, e a ideia predominante é a de que só se aprende em sala, ouvindo a voz do professor. Dizer-lhes que aprendem também conversando sobre a última aula na padaria da esquina sempre causa surpresa, mesmo no presencial. Para mim, diante da quebra do nosso "acordo" original, a questão da apropriação, por parte dos alunos, de sua aprendizagem tornou-se central, e, na próxima seção, discuto as bases nas quais passei a trabalhar para contribuir um pouco mais, na medida do possível, para essa apropriação.

\section{O QUE COUBE NO ENSINO REMOTO (ATÉ AGORA)?}

Tanto no primeiro quanto no segundo semestre de 2020, fui alocada a uma disciplina sobre tecnologias e mídias na educação. É uma matéria obrigatória do curso de Pedagogia e eletiva das outras Licenciaturas e do domínio adicional Tecnologias e Mídias Digitais da universidade, e, por isso, relativamente popular. Os grupos, porém, eram bastante diferentes: o de 2020.1 era composto, predominantemente, por alunos de $1^{\circ}$ e $2^{\circ}$ período da Pedagogia. Em 2020.2, a maioria era de alunos das outras Licenciaturas - Biologia, Letras etc. -, muitos já nos dois últimos períodos de seus respectivos cursos, ou seja, era uma turma de estudantes mais maduros. De qualquer modo, as turmas que tenho tido na disciplina tendem a ser fortemente heterogêneas de diversas formas, e preciso sempre considerar, também, como parte dos propósitos de qualquer 
ação que venha a propor, a necessidade de acomodar uma ampla gama de habilidades, possibilidades e limites.

No início de março, tive, com a turma daquele semestre, alguns encontros presenciais ao longo das duas semanas que se passaram até ser decretado o fechamento do campus da instituição, e já estava com quase todos os nomes e rostos em mente. Com a turma do semestre seguinte, acabei por conhecê-los apenas como nomes escritos sobre um retângulo preto, ou fotos de rostinhos sorridentes, pois muitos preferiam não abrir suas câmeras, ainda que participassem, ocasionalmente, por áudio. O mesmo se dá agora em 2021.1; porém, têm sido experiências totalmente diferentes, não apenas porque se tratou/trata de grupos de pessoas diferentes, com expectativas também bastante diferentes, mas, crucialmente, porque não foi possível o usual encontro de "acolhimento" presencial considerado uma "boa prática" por especialistas em EaD.

A lógica que adotei para pensar inicialmente a adaptação da disciplina para a situação não presencial baseou-se em dois eixos fundantes: (1) inclusão; (2) articulação "teoria-prática". Por um lado, tomando como base aquela espécie de máxima que orienta a determinação de requisitos técnicos para cursos em EaD - a ideia de que a corrente é tão forte quanto seu elo mais fraco, que já mencionei -, pensei em adotar várias mídias alternativas para apoiar contatos pessoais, com preferência por mídias assíncronas, que são menos custosas em termos de consumo de dados - pensando que alguns pacotes de dados para celulares oferecem acesso ilimitado a alguns serviços. Por outro lado, objetivando promover uma forma de articulação "teoria-prática" baseada na apropriação de ideias acadêmicas em exercícios de leitura de mundo, propus uma série de atividades que combinaram trabalho conceitual - leituras e discussões de textos acadêmicos - com buscas e discussão de matérias on-line sobre assuntos do momento vivido - em duplas ou trios -, complementadas com reflexões individuais.

Vejamos primeiramente, porém, algumas questões mais instrumentais: para a turma do primeiro semestre de 2020, na correria que se sucedeu à implantação da quarentena no Estado do Rio de Janeiro, acabei utilizando dois grupos no Facebook e um grupo no WhatsApp, além do espaço no Google Drive que já havia organizado na preparação para o semestre. A universidade dispõe de um sistema de administração acadêmica que permite envio de e-mails em bloco para a turma inteira, que é bem útil para os professores - não temos que criar listas separadamente -, mas nem sempre produtivo, pois sistemas de e-mail diferentes às vezes direcionam as mensagens recebidas por esse sistema para a caixa de spam. Utilizo esse sistema com parcimônia, mas, no início de 2020.1, não houve outra alternativa.

Acho que levei duas semanas até conseguir que todos compreendessem como seria a nova dinâmica e acessassem todos os espaços, seguindo as seguintes etapas: (1) primeiro contato com os alunos por e-mail em bloco - primeira semana da quarentena - para verificar a situação de cada um no tocante a equipamento, acesso à internet e espaço para trabalho; (2) com base nas informações obtidas nesse levantamento, montei um grupo de WhatsApp reunindo toda a turma - tratava-se da única mídia da qual todos já eram usuários -, para possibilitar um acolhimento inicial e a (re)organização das atividades - a primeira atividade foi realizada com apoio desse aplicativo; (3) na sequência, criei os dois grupos no Facebook - Figura 4 -, e a única aluna que não era usuária dessa plataforma gentilmente se prontificou a criar um perfil para acompanhar a turma. Um grupo - Café com Bolo, aberto para postagens de todos - era para trocas informais, e 
o outro para o trabalho na disciplina - no qual apenas eu poderia postar, mas qualquer um poderia comentar. Todos os trabalhos e discussões foram conduzidos nessa plataforma, com apoio de e-mail, WhatsApp e ligações telefônicas, em alguns casos; (4) videoconferências por Zoom foram realizadas em momentos específicos do semestre - sessões de uma hora com a turma dividida em grupos, pois eram muitos -, com fins, basicamente, de cultivar relações e dar uma espécie de apoio "pastoral". A utilização de e-mail foi minimizada, a pedido dos próprios alunos, e o WhatsApp permaneceu em uso - uso esporádico do grupo criado inicialmente, mas uso continuado para comunicação um a um. Foi mantida a pasta no Google Drive que eu havia montado antes do início do ano letivo, contendo o programa da disciplina e um repositório de todas as leituras - básicas e complementares - em arquivos PDF.

Figura 4: Prints de tela dos grupos criados no Facebook para a turma de graduação de 2020.1

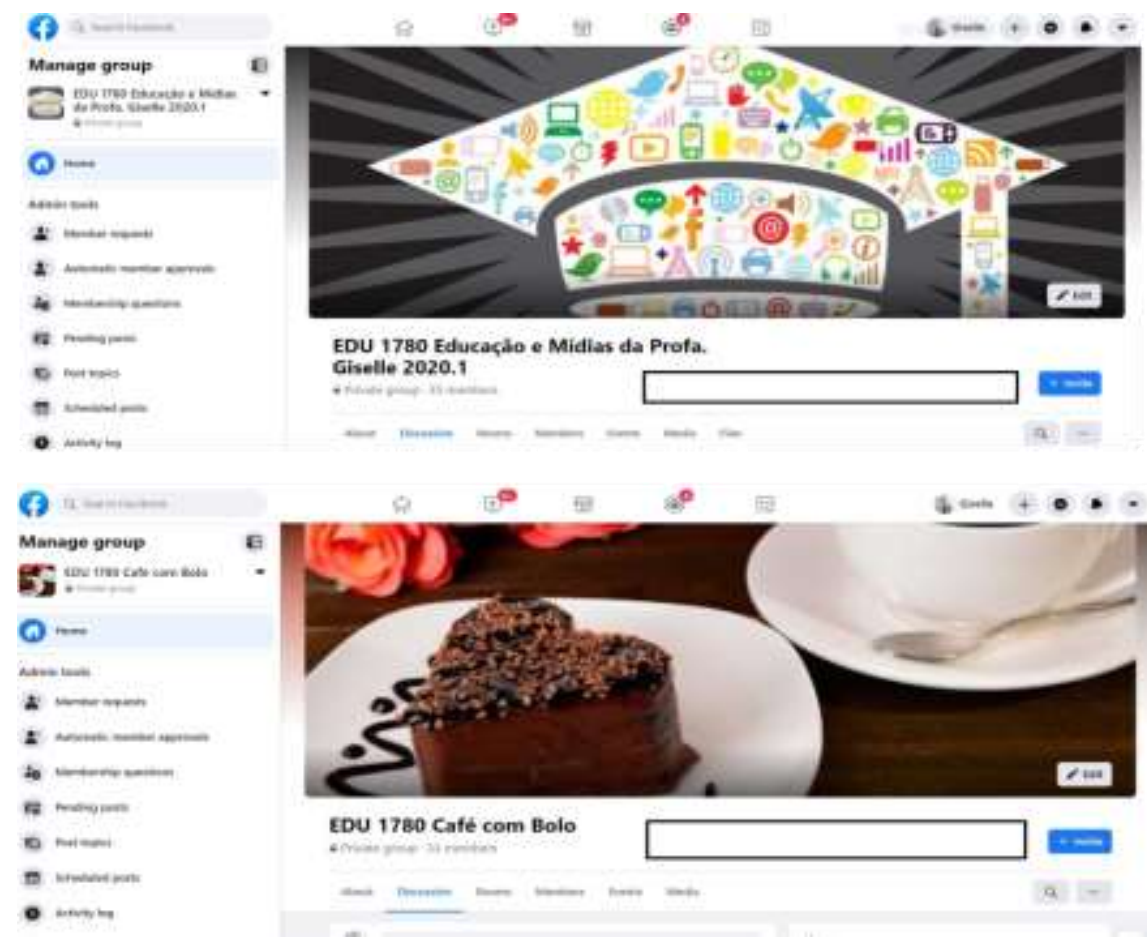

Fonte: Arquivo pessoal da autora.

Para o segundo semestre, recebemos uma orientação institucional no sentido de que procurássemos concentrar nossos usos de espaços on-line no Ambiente Virtual de Aprendizagem (AVA) interno, baseado no Moodle, gerido e mantido pela unidade que coordena a oferta de EaD da universidade. A plataforma realmente oferece uma grande vantagem com relação à gestão da avaliação - em 2020.1, recebi trabalhos via múltiplos canais, e o esforço para organizá-los foi insano, pois havia entregas quinzenais individuais de uma turma de 36. Além disso, o agendamento e acesso ao Zoom foram integrados no ambiente, o que também é bem útil. Então, para a turma do segundo semestre, o espaço ficou conforme mostrado na Figura 5. 
Figura 5: Configuração de disciplina da graduação em 2020.2

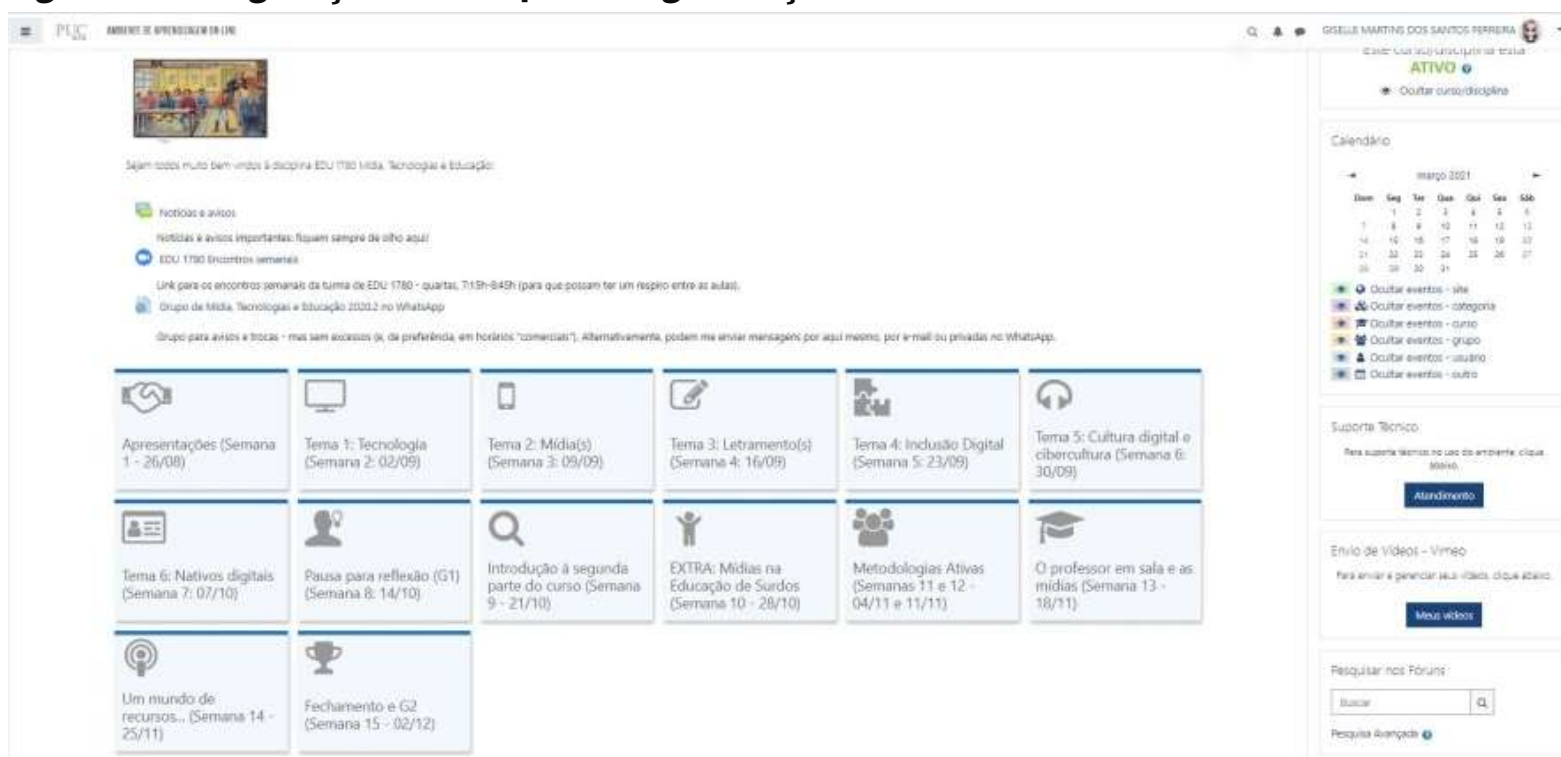

Fonte: Elaborado pela autora.

Preferi a configuração em blocos, que deixa a tela mais limpa e funciona bastante bem no celular, e usei ícones e indicações claras de temas e datas de encontros síncronos para criar um mapa/guia do curso diretamente na homepage da disciplina. Ao clicar em um bloco, abre-se uma janela com detalhes, conforme mostrado na Figura 6.

Figura 6: Configuração de blocos no Moodle

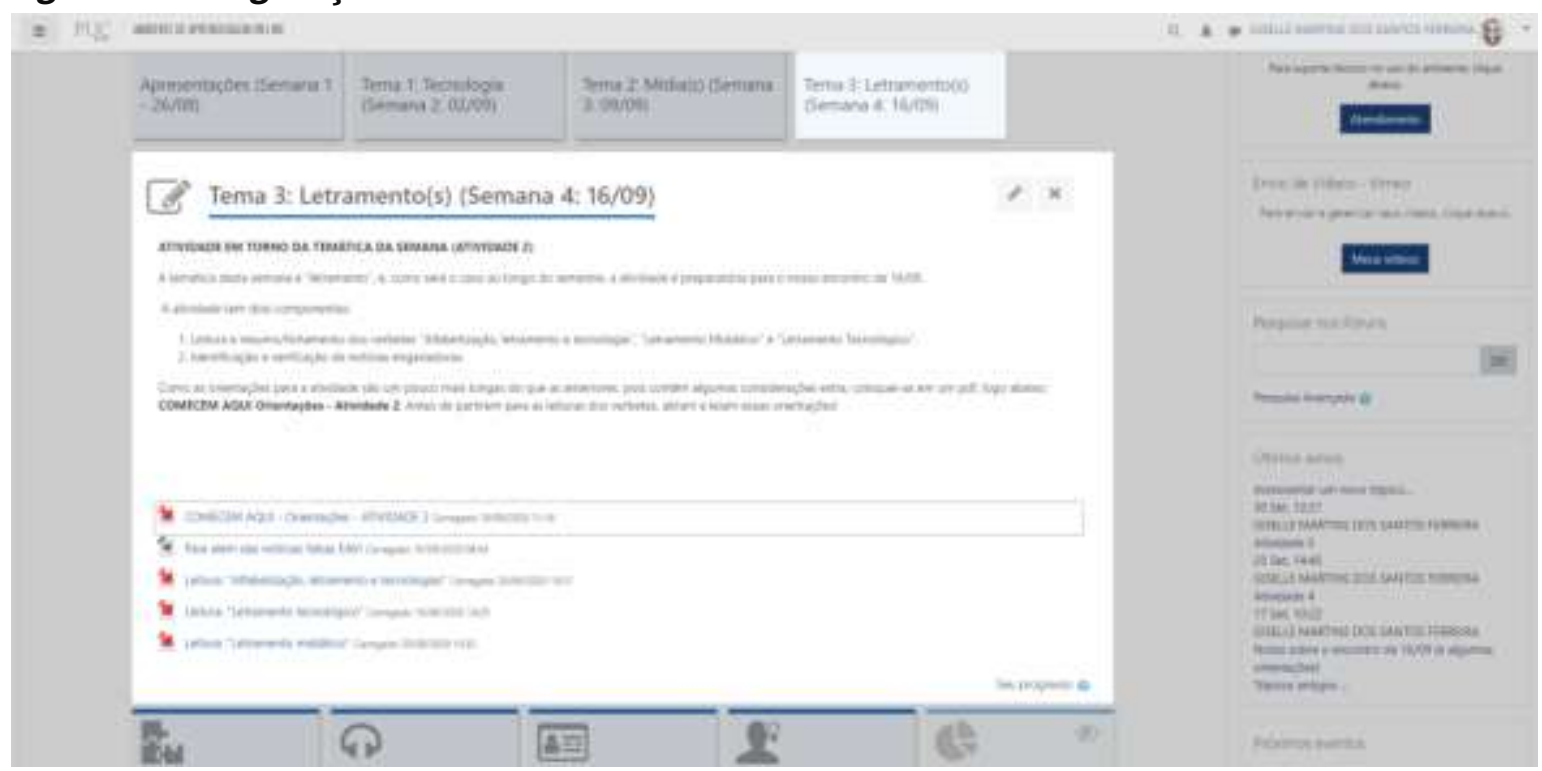

Fonte: Elaborado pela autora.

Nada disso é novo - são pequenos detalhes de design instrucional familiares a professores experientes no desenvolvimento de cursos para a EaD -, e o uso dos arquivos no formato PDF é algo que muitos da área do e-learning dirão ser uma "má prática". Aqui entram as especificidades do contexto e a necessidade de flexibilidade, tanto no acesso a orientações e textos, para que 
pudessem ser lidos sem que o aluno estivesse necessariamente on-line, quanto no tocante a prazos. $O$ acesso à internet no Brasil é mesmo bem frágil, e tive que reagendar alguns encontros - com a turma de pós e com o grupo de orientandos - por total falta de conexão minha, pois até - 4G pelo celular estava restrito nessas ocasiões. Outra coisa é que os layouts "quebradinhos" de treinamentos on-line não são, em minha opinião, apropriados para toda e qualquer experiência educacional on-line. De qualquer forma, elementos on-line e off-line, síncronos e assíncronos, sempre precisam ser pensados de forma integrada, e precisamos estar sempre prontos para improvisar alternativas. Problemas de conexão à internet são os ossos do ofício do trabalho online com a infraestrutura que temos à nossa disposição; mas, e as questões pedagógicas?

Bem, aqui me considero bastante privilegiada com a disciplina: se mídias e tecnologias, antes do início da pandemia, estavam em pautas de discussão específicas e eram ainda tratadas por muita gente como um mero "adendo" à formação de professores, as coisas mudaram radicalmente com o fechamento das instalações das instituições de ensino - em todos os níveis. Nesse contexto, os assuntos dos quais usualmente trato na disciplina tornaram-se fundamentais de uma forma não imaginada antes. Pensei, então, que o ideal seria adaptar, de forma bastante explícita, o material da discip lina ao momento que estávamos vivendo, aproveitando as vivências de aprendizagem remota dos próprios alunos, bem como elementos do contexto mais amplo no qual estávamos inseridos, como fonte de material a ser integrado no trabalho da disciplina.

A partir de uma estrutura de atividades com produtos a serem entregues semanal ou quinzenalmente para fins de avaliação continuada, consegui manter o direcionamento que havia determinado ao montar o programa original da disciplina, que combinava elementos de metodologias ativas, tais como aprendizagem entre pares, sala de aula invertida e aprendizagem por projeto (PISCHETOLA; MIRANDA, 2019). Dessa forma, conduzi os alunos em reflexões sobre a experiência de aprender a distância como base para encorajá-los a repensarem suas concepções sobre aprender, ensinar, a aula, a sala de aula e os objetos que fazem parte do cenário da educação, digitais ou não. E, como faço sempre, encorajei-os a manterem um "Diário de Aprendizagem" com anotações, questões, recortes de leituras - e de materiais midiáticos sobre os assuntos tratados -, para a composição de um portfólio a partir do qual seria feita a avaliação.

Para ilustrar, o Apêndice A inclui uma das atividades propostas durante o semestre de 2020.2, relacionada ao tema letramento midiático. O objetivo central da atividade era, no contexto do assunto em tela, proporcionar aos alunos uma oportunidade de explorarem os problemas envolvidos na divulgação de "notícias enganadoras" - que incluem as famigeradas fake news -, bem como, em particular, refletirem sobre o processo de verificação de informações. As orientações por escrito foram, subsequentemente, exploradas em discussão síncrona de forma a explicitar o pensamento pedagógico que sustentou a criação da atividade. Desse modo, os alunos também foram convidados a refletir sobre questões pedagógicas, ou seja, convidados a pensarem como professores em formação, que é como sempre os trato. Assim, a discussão pode avançar não apenas em relação ao conteúdo - o tema, tratado em artigos ou verbetes de Mill (2018) -, mas também à forma, isto é, o modo como a atividade foi pensada, o que me parece essencial em um contexto de trabalho com futuros docentes - e aqui incluo o pessoal da Comunicação e de outras áreas que expressa o desejo de atuar na comunicação pública da ciência. 
Nesse sentido, a avaliação na disciplina sempre contém, minimamente, um componente reflexivo, e, no segundo semestre, cheguei a um formato que achei bastante produtivo - que manterei para o semestre atual, com alguns ajustes para melhorar a apresentação. As orientações estão mostradas no Apêndice B. A proposta envolve um elemento de role play que demanda a mobilização de conhecimentos em um contexto profissional imaginário, destacando a noção de que é o pensamento pedagógico que precisa orientar a ação docente, não a disponibilidade de mídias. Acho isso bem mais interessante do que uma prova ou mera atividade de produção instrumental - de mídias como vinha fazendo no laboratório que temos disponível para essa disciplina no presencial.

Uma coisa que não consegui, no final do semestre, foi fazer com a turma a avaliação da disciplina. Faço isso todo semestre usand o como base o formulário mostrado no Apêndice C, mas, confesso: cheguei ao final dos semestres de 2020 quase que inteiramente "sem gás". Esse tipo de avaliação é uma forma importante de ação docente, pois, além de me dar subsídios para refletir sobre o que faço, também constitui uma oportunidade para os professores em formação sob minha responsabilidade pensarem sobre avaliação, que é um assunto em geral negligenciado. Surpreendem-se, quase sempre, com a proposta e com meus comentários sobre avaliação ser algo integral à aprendizagem, "instantâneos", que dizem alguma coisa sobre um processo, que é algo que se desenrola no tempo, porém não dizem tudo.

\section{CONSIDERAÇÕES FINAIS}

Há muito mais que poderia ser dito sobre essas experiências, mas vou destacar alguns pontos que considero essenciais:

a) Como muitos especialistas vêm dizendo, não faz sentido simplesmente substituir horasaula por horas em vídeoconferências. Isso causa exaustão simplesmente. É preciso pensar em formas de manter o contato pessoal, com certeza, mas o contexto que estamos vivendo não é o que tínhamos antes, ou seja, as pessoas não estão em casa por vontade própria. E, em casa, as demandas também mudaram - aumentaram para muita gente -; inclusive, com o relaxamento do isolamento social, deu-se o retorno gradativo de muitos a seus respectivos locais de trabalho. Enfim, as circunstâncias dos alunos e as nossas são múltiplas. Aliás, câmeras fechadas refletem tanto as formas de se lidar com essa multiplicidade quanto a questão perene da "presença sem presença", mencionada no próximo item - no final de encontros no Zoom, sempre há remanescentes que parecem ter estado presentes dessa forma;

b) Também, como reza a cartilha da EaD, a aprendizagem não presencial demanda muito mais autonomia e organização do aprendiz. Não penso, entretanto, que essa questão seja relevante apenas à aprendizagem remota: a distância apenas torna crítico um problema já existente. No campus, a agenda semanal dos alunos tende a girar em torno da presença em sala de aula. As próprias expectativas dos alunos parecem girar em torno da ideia de que só se aprende em sala de aula - mesmo que admitam que, com frequência, seu estar em sala é apenas "de corpo presente”, em uma "presença sem presença”, ou seja, o aluno 
está suficientemente ali para evitar uma falta na pauta, mas, durante aquele tempo, passa a habitar algum "lugar feliz" em sua mente, alheio ao que se passa ao seu redor. Fora do campus, sem sessões de Zoom a substituir a hora-aula, fica mais óbvia a necessidade de organização. Em particular, no contexto de formação de professores, acho essencial mostrar não apenas que a sala não é o único local de aprendizagem, mas, crucialmente, que eles precisam se apropriar do processo de forma mais ampla. Precisamos lhes dar ideias, orientações e, em especial, oportunidades para ensaiarem essa apropriação;

c) Por que não usei o Moodle no primeiro semestre? Sinceramente, porque não quis. Fui usuária do Moodle no passado, até cheguei a fazer uma instalação em um computador quando a instituição na qual eu trabalhava estava testando diferentes AVAs, e não gostei do excesso de parâmetros e controles. Esse excesso sempre me pareceu como "soluções em busca de problemas", para adotar uma leitura de Selwyn (2017) sobre a questão do solucionismo tecnológico na educação. Desde então, as coisas mudaram um pouco na plataforma, e, realmente, faz sentido, para alunos com todas as disciplinas em modo remoto, que haja um espaço único onde possam acessar tudo que precisam. A experiência em 2020.1 me mostrou que é bastante difícil substituir a ideia do AVA pela de Ambiente Pessoal de Aprendizagem (APA), ou seja, um espaço híbrido, on-line e off-line, que reúne diferentes mídias e suportes (FERREIRA; CASTIGLIONE, 2018). Há, também, a questão da parte mecânica da avaliação, que já mencionei acima; no entanto, ainda não entendo como se pode sustentar que o Moodle é uma "plataforma construtivista". Além disso, tenho várias questões e objeções relativas a direitos autorais e direitos de imagem - tanto que, em geral, não gravo encontros no Zoom. Enfim, é uma solução de compromisso, no meu entender, um assunto para outro texto.

Em momento algum quis dizer que o que penso e faço é modelo para outras pessoas! Pelo contrário: no final do primeiro semestre, especificamente, recebi algum feedback bem negativo de uma aluna, o qual me saltou aos olhos porque muitos participaram, naquele semestre, da avaliação institucional que o corpo discente faz de seus professores, e essa participação não seria o usual esperado. Creio que alguns - ou muitos, não saberia estimar sem um levantamento formal - esperavam aquilo que acham que é a EaD: aulas expositivas gravadas. Eu, particularmente, acho esse formato quase sempre bastante tedioso, quer sejam utilizados slides ou as clássicas "cabeças falantes". De fato, na Open University, aulas gravadas foram abandonadas muito cedo na história da instituição, a qual foi favorecendo gêneros midiáticos mais criativos e interessantes, como docudramas, dramas históricos, animações etc. (WEINBREN, 2015).

Outra questão recente que começa a me preocupar é o uso da velocidade de playback acelerada, ou seja, assistir a um vídeo com velocidade dobrada sem perda da altura da voz, como é possível na plataforma YouTube e com certos aplicativos. É uma experiência bastante estranha, mesmo com o tratamento dado à voz, e creio que pagaremos um preço por isso, com tantos jovens adotando essa estratégia com frequência cada vez maior. Creio que há, aqui, um tópico de pesquisa para os próximos anos. 
Por fim, a questão mais importante: para que mais um artigo sobre experiências na educação durante a pandemia? Parece haver muitos gurus e especialistas de prontidão principalmente para vender treinamentos -, e as lives, postagens e artigos se multiplicam com dicas, estratégias, defesas de rótulos específicos, enfim, às vezes me sinto próxima de uma forma de "infoxicação" dessas coisas e tudo que desejo é simplesmente ler um livro impresso. Nomes novos para coisas velhas, nomes velhos para coisas novas, em suma, a busca por estabelecer territórios acadêmicos não cessa nunca. Nesse contexto, penso ser válido lembrarmos de que, talvez, o que precisemos, é de experimentação, criatividade e, crucialmente, mais reflexão. Sim, é preciso saber "onde clicar", mas isso se pode descobrir apenas clicando, atentando que, neste mundo digital, é possível desfazer quase tudo. O que não dá para desfazer com facilidade são as expectativas e preconcepções, nossas, de nossos alunos e de nossas instituições. Para tanto, é preciso diálogo e reflexão, e, nesse sentido, espero ter contribuído meus dois centavos ao presente dossiê.

\section{REFERÊNCIAS}

CRUZ, E. G. De volta ao ciberespaço: uma alucinação consensual acadêmica'i. In: BANNELL, R. I.; MIZRAHI, M.; FERREIRA, G. Deseducando a educação: mentes, materialidades e metáforas. Rio de Janeiro: PUC-Rio, 2021. Disponível em: http://www.editora.puc-rio.br/media/Deseducando_a_educacao_ebook\%20(1).pdf. Acesso em: 22 abr. 2021.

FAUVILLE, G. et al. Zoom Exhaustion and Fatigue Scaleii. Social Science Research Network Repository, 15 fev. 2021. Disponível em: http://dx.doi.org/10.2139/ssrn.3786329. Acesso em: 22 abr. 2021.

FERREIRA, G. Educação e Tecnologia: visões periféricas (http://visoesperiféricas.blog) - blog acadêmico da autora, especialista na área dos Estudos Críticos da Educação e Tecnologia

FERREIRA, G. M. S.; CASTIGLIONE, R. G. M. TIC na Educação: Ambientes Pessoais de Aprendizagem na perspectiva e práticas de jovens siii. Educação e Pesquisa, v. 44, 2018. Disponível em: http://dx.doi.org/10.1590/s1678-4634201702153673. Acesso em: 22 abr. 2021.

FERREIRA, G. M. S.; LEMGRUBER, M. S. Tecnologias educacionais como ferramentas: Considerações críticas acerca de uma metáfora fundamentaliv. Arquivos Analíticos de Políticas Educativas, Arizona, v. 26, p. 112, 2018. Disponível em: http://dx.doi.org/10.14507/epaa.26.3864. Acesso em: 22 abr. 2021.

HOLMBERG, B. Theory and Practice of Distance Educationv . Londres: Routledge, 1989.

LEMGRUBER, M. S.; FERREIRA, G. M. S. Metáforas Fundamentais da Tecnologia Educacionalvi Educação em Foco, Juiz de Fora, v. 23, n. 1, p. 15-38, jan./abr. 2018. Disponível em: http://dx.doi.org/10.22195/24475246v23n120183351. Acesso em: 22 abr. 2021.

MILL, D. (Org.). Dicionário Crítico de Educação e Tecnologias e de Educação a Distânciavii. Campinas: Papirus, 2018.

MOROZOV, E. To save everything, click here: The folly of technological solutionism ${ }^{\text {viii }}$. New lork: Penguin Books, 2013.

PISCHETOLA, M.; MIRANDA, L. T. Metodologias Ativas: uma solução simples para um problema complexo? ?. Revista Educação e Cultura Contemporânea, Rio de Janeiro, v. 16, n. 43, p. 30-56, 2019. 
Disponível em: http://periodicos.estacio.br/index.php/reeduc/article/view/5822/47965983. Acesso em: 22 abr. 2021.

SELWYN, N. Distrusting Educational Technology: Critical Questions for Changing Times ${ }^{x}$. New York: Routledge, 2014.

SELWYN, N. Educação e Tecnologia: questões críticas ${ }^{x i}$. In: FERREIRA, G. M. S.; ROSADO, L. A. S.; CARVALHO, J. S. (Org.). Educação e Tecnologia: abordagens críticas. Rio de Janeiro: SESES, 2017. Disponível em: https://ticpe.files.wordpress.com/2017/04/ebook-ticpe-2017.pdf. Acesso em: 22 abr. 2021.

VALLE, L.; BOHADANA, E. D. B. Sobre presença e distância. Reflexões filosóficas acerca da formação online ${ }^{\text {xi. }}$ In: MILL, D.; MACIEL, C. (Org.). Educação a distância: elementos para pensar o ensinoaprendizagem contemporâneo. São Paulo: EdUFMT, 2013.

WATTERS, A. HACK EDUCATION. Blog acadêmico. Disponível em: http://hackeducation.com/

WEINBREN, D. The Open University: a history xiii. Manchester: Manchester University Press, 2015.

WELLER, M. 25 Years of EdTech ${ }^{\text {xiv }}$. Athabasca: Athabasca University Press, 2020. Disponível em: https://www.aupress.ca/books/120290-25-years-of-ed-tech/. Acesso em: 22 abr. 2021.

WELLER, M. The Digital Scholar: How technology is transforming scholarly practice ${ }^{x v}$. London: Bloomsbury, 2011. Disponível em: https://bit.ly/3xiXV72. Acesso em: 22 abr. 2021.

WELLER, M. The EdTechie (http://blog.edtechie.net/) - blog acadêmico de Martin Weller, especialista na área de Educação Aberta a Distância. 


\section{APÊNDICE A - EXEMPLO DE ATIVIDADE CONDUZIDA COM TURMA DA GRADUAÇÃO EM}

2020.2

\section{ORIENTAÇÕES PARA A ATIVIDADE 2}

\section{Algumas considerações gerais}

Vivemos um momento de grande confusão, um momento no qual as pessoas parecem ter perdido tanto a capacidade de separar informações válidas de bobagens (daí o grande problema das fake news), quanto de argumentar de forma lógica e coerente: há muita gente "ganhando" discussões "no grito" ou a partir de argumentos de autoridade duvidosos.

Argumento de autoridade, dito de forma bem simples, é a nossa boa e velha "carteirada": alguém faz uma afirmação qualquer e os ouvintes aceitam porque a pessoa ocupa algum lugar percebido como lugar de autoridade ou poder. Por exemplo, circula nas redes uma afirmação de que a covid-19 foi criada (em alguns relatos, impulsionada) pela nova rede $5 \mathrm{G}$ (tecnologia de telecomunicações mais avançada do que o $4 \mathrm{G}$ que temos no Brasil, já funcionando em outros países, notadamente, a China); isso parece ter partido de um "médico" estadunidense, e circula amplamente aqui como um "argumento de autoridade", pois, afinal, quem propôs foi um "médico".

Notem as aspas duplas no parágrafo acima: em inglês, são conhecidas como scare quotes, ou aspas do medo/temor/pânico. Aspas podem indicar ênfase, mas aqui indicam desconfiança, pois não há evidência científica alguma de que isso seja verdade. De fato, o tal "médico" foi descredenciado da profissão.

Alguns pontos de atenção aqui. Em primeiro lugar, o que escrevi acima não saiu da minha cabeça, de grupos no WhatsApp nem do Facebook: saiu de fontes confiáveis que fizeram uma pesquisa investigativa sobre o assunto - um jornalista e uma médica conhecidos meus, em quem confio bastante, por sua formação e experiência profissional. Pessoalmente, não tenho condições de avaliar uma afirmação dessa natureza (não tenho formação nenhuma na área da saúde), então preciso buscar fontes que tenham a condição de fazer essa avaliação para mim.

Parte do problema que estamos vivendo com o excesso de informação que circula pela internet pode ser compreendido como uma infoxicação, termo criado por um pesquisador espanhol que expressa a ideia de "intoxicação pelo excesso de informação".

Um segundo ponto é a questão da confiança. Parte do problema tem a ver com a perda de confiança no conhecimento científico e, de forma mais geral, acadêmico. De certo modo, é um paradoxo, pois, ao mesmo tempo que somos bombardeados por opiniões com base em "argumentos de autoridade" (alguém "famoso" ou "poderoso" diz algo, as pessoas aceitam sem questionar), vivemos um desprezo pela autoridade, compreendida de forma mais específica: o conhecimento construído por acadêmicos, cientistas, pesquisadores, enfim, estudiosos que dedicam seu tempo e energia para compreender seus respectivos assuntos de escolha.

Nesse contexto, fica clara a importância do letramento (em suas diversas classes e tipos): para que não nos sufoquemos, para que saibamos identificar o que vale e o que não vale, o que é legítimo e o que é apenas opinião sem fundamento ("achismo"). Todos temos o direito de ter nossas próprias opiniões, mas todas as opiniões não são iguais, pois sua "força" depende da fundamentação de apoio.

Nesta atividade, então, vocês começarão com a leitura dos verbetes para que tenham uma base sobre o que está envolvido no letramento, de forma geral. Na sequência, irão focalizar em um 
problema fundamental para a área do letramento midiático: as notícias enganadoras (que incluem, como verão abaixo, as fake news).

\section{Parte 1: Leitura}

Algumas orientações para a leitura:

- Atenção às definições ("o que é"): identifiquem as definições e tentem colocá-las em suas próprias palavras;

- Nesse espírito, comparem e contrastem o que os diferentes verbetes dizem sobre o mesmo tema (especificamente, as definições de "letramento" e como se relacionam com a ideia de "alfabetização");

- Como sempre, leiam com atenção (mais de uma vez), rabisquem, tomem notas e questionem o texto;

- Usem seus respectivos Diários de Aprendizagem para guardar suas notas, seus questionamentos e ideias;

- Se houver algo que não entendam, perguntem!

\section{Parte 2: Verificando notícias (potencialmente) enganadoras (incluindo fake news)}

Em tradução literal (é uma expressão da língua inglesa que já, já entrará nos dicionários nacionais - se já não entrou!), fake news seriam "notícias falsas". Então, em geral, a ideia de fake news implica a ideia de mentira, falsidade. Porém, o problema aqui não é apenas a oposição mentira vs. verdade - e isso torna nosso trabalho de identificar o que "não presta" bem mais complicado. Por isso vamos enquadrar as fake news em um esquema mais amplo de "notícias enganadoras". A imagem abaixo foi retirada do site da EAVI (https://eavi.eu/), uma associação que faz um belo trabalho de letramento midiático na União Europeia (há muitos recursos em português). Deixarei um jpg da imagem no Bloco também (Para além das notícias falsas - EAVI), para que vocês possam ver os detalhes mais claramente.

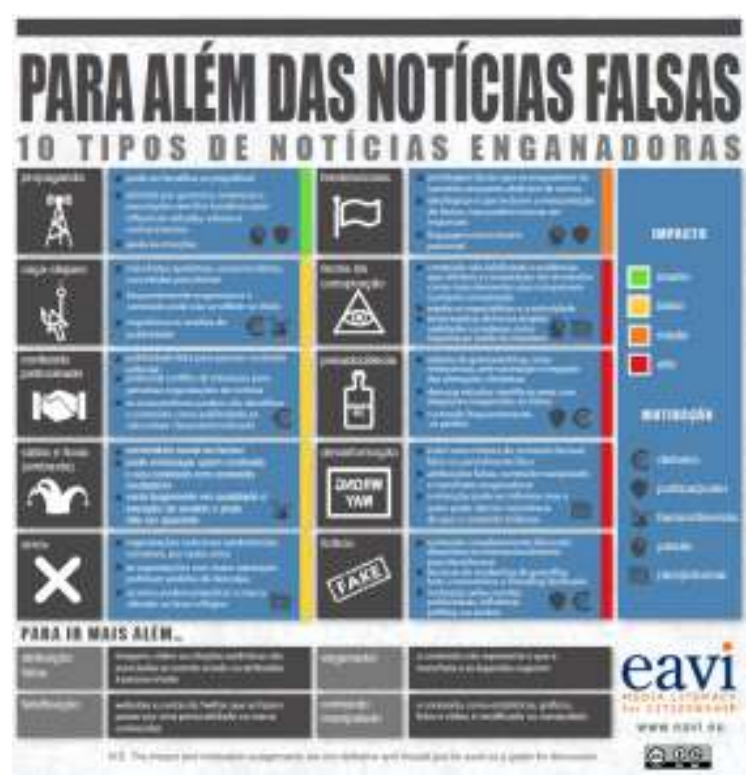

Fonte: https://eavi.eu/wp-content/uploads/2017/07/PT-EAVI-Fakenews-Pict.png 
A imagem mostra 10 tipos de notícias enganadoras. Apenas uma categoria lida com fake completo, ou seja, algo que é inteiramente fictício. As outras nove lidam com diferentes nuances do problema. Por exemplo, teorias da conspiração são diferenciadas de material fictício, pois têm características específicas: o terraplanismo, por exemplo, a crença de que a terra não é redonda, vem ganhando espaço no Brasil (a partir de sua importação dos EUA, como muitas outras teorias dessa natureza), rejeita a ciência (e não é a ciência recente, mas argumentação e raciocínio milenar, de fato). Na classificação da EAVI, o terraplanismo poderia ser visto, também, como pseudociência, pois a argumentação de defesa dessa teoria incorpora elementos do fazer científico (em particular, uso de experimentos para coleta de "dados empíricos" e argumentação a partir desses "dados").

Não é que essas formas de falsificação e distorção sejam novas, mas sim que a internet permite sua disseminação em uma escala sem precedentes. Assim, todos precisamos desenvolver, minimamente, uma forma de desconfiança com relação ao que acessamos pela internet.

Uma das principais linhas de atuação no desenvolvimento do letramento midiático é, exatamente, a criação de estratégias para podermos "filtrar" o que encontramos na internet. Não é uma questão simples, pois, essa identificação demanda, com frequência, conhecimentos específicos de diversas áreas, ou seja, não é algo que uma única pessoa consiga fazer sem a ajuda de especialistas.

Nesse sentido, há diversas iniciativas nacionais que envolvem jornalistas investigativos e especialistas de áreas diversas na identificação de conteúdo duvidoso. Vejam alguns exemplos:

a) Agência Lupa: https://piaui.folha.uol.com.br/lupa/ Associada à Folha de São Paulo

b) Fato ou Fake: https://g1.globo.com/fato-ou-fake/ Associada ao Grupo Globo

c) E-Farsas: https://www.e-farsas.com/ Iniciativa de um analista de sistemas, agora integrada ao sistema $\mathrm{R} 7$

d) Aos Fatos: https://aosfatos.org/ Iniciativa de jornalistas investigativos

Se entrarem nos sites, verão que cada um tem, também, sua própria classificação das notícias que investigam: a Lupa, por exemplo, tem uma etiqueta "É cedo para dizer", que indica não haver ainda evidências para sustentar alguma afirmação; aqui caberia o uso de cloroquina no combate à covid-19, sugerido pelo Presidente Trump (quando foi sugerido - parece que já há evidências fortes contra isso). Aliás, na sequência de afirmações estapafúrdias, Trump sugeriu que as pessoas talvez pudessem combater a doença com injeções de detergente, gerando grande comoção no meio da Saúde lá - infelizmente, quase que imediatamente, a cidade de Nova lorque, uma das que mais sofreu com a doença nos EUA inicialmente, registrou um aumento significativo nas internações por envenenamento - isso mostra bem a falta que fazem diferentes formas de letramento (não apenas midiático, mas também científico)!

Esses exemplos ilustram uma categoria de notícias que é crítica para todo mundo no momento, que são as alegações sobre diferentes formas de proteção contra (e, até mesmo, cura da) covid-19. Vejam esta notícia sobre uma "cura" com chá de limão, alho e jambu: https://piaui.folha.uol.com.br/lupa/2020/04/23/verificamos-alho-jambu-coronavirus/.

Vejam, em particular, o procedimento que a agência utilizou para verificação da alegação: consultaram um especialista! 
A tarefa de vocês, então, é identificar e refletir (sobre) a verificação de três exemplos de notícias enganadoras. Cada exemplo deve ilustrar uma categoria diferente dos 10 tipos de notícias mostradas na imagem.

Como fontes para encontrar afirmações e notícias duvidosas, podem usar o que quiserem, inclusive memes que possam ter recebido por redes sociais e WhatsApp, mas precisam verificar nos sites listados (ou em outros que conheçam e que façam o mesmo tipo de trabalho). Alternativamente, podem pesquisar notícias já verificadas diretamente nos sites que listei acima, para facilitar o processo - realmente, a produção dessas loucuras é tão veloz que é bem capaz de vocês encontrarem afirmações ainda não verificadas e que necessitariam de consultas a especialistas, talvez. 0 importante é que compreendam o processo de verificação nos exemplos que escolherem.

IMPORTANTE: Caso escolham escrever sobre esta atividade para incluir como parte do seu G1, precisarão apresentar uma descrição sucinta e coesa desse processo, bem como uma argumentação coerente relativa à classificação dentro do esquema dos 10 tipos de notícias enganadoras mostrados na imagem.

Quanto aos temas em questão, há muitos temas atuais relativos à própria covid-19 (incluindo os números de afetados sendo divulgados por agências diferentes), ao contexto político, à própria situação da educação, enfim, podem escolher o que quiserem. Porém, sem partidarismos, pessoal: é um exercício de raciocínio lógico e conceitual, então trabalhem com as ideias, evidências e argumentos.

\section{Bom trabalho!}




\section{APÊNDICE B - TRABALHO FINAL DE DISCIPLINA DA GRADUAÇÃO (2020.2)}

Querid@s, para "amarrar” a experiência na disciplina, vocês terão as 3 semanas finais do semestre para dedicarem à confecção de seus trabalhos finais. Os encontros síncronos no Zoom serão dedicados a apoiá-los nesta tarefa.

Leiam tudo antes dos encontros para podermos discutir questões específicas!

PRAZO DE ENTREGA: 09 de dezembro, sem extensões!

PROPOSTA

Imaginem o seguinte cenário.

Vocês estão em busca de uma colocação como professores (em uma escola ou instituição de ensino superior), e, em meio à pandemia, a etapa inicial do processo seletivo requer que vocês enviem por e-mail alguns materiais que serão usados por uma banca ou comissão de seleção para apoiar uma primeira triagem dos candidatos. As entrevistas serão conduzidas depois, apenas com os candidatos que apresentarem os melhores materiais!

O trabalho que vocês deverão me entregar será composto exatamente dos materiais que teriam que preparar para esse processo seletivo imaginário, que seriam os seguintes:

\section{1) Um texto em formato de carta;}

2) Uma seleção de recursos midiáticos produzidos ou selecionados por vocês.

\section{A carta}

Então, a primeira parte desses materiais é uma carta na qual vocês precisam apresentar à comissão/banca de seleção os fundamentos de sua abordagem pedagógica no tocante às mídias e tecnologias digitais. Em outras palavras, precisam responder à seguinte questão disparadora: "Qual o papel das mídias e tecnologias digitais em sua prática?".

A carta, então, poderá ser feita como uma escrita reflexiva focalizada na questão disparadora acima, que lhes exigirá que pensem no papel possível para mídias e tecnologias nas suas vidas futuras como docentes.

A exigência aqui é que deverão articular suas ideias com, pelo menos, três dos conceitos que vimos na disciplina. Além disso, precisam explicitar e explicar no texto suas escolhas para o item (2), ou seja, os recursos midiáticos. $O$ texto deve ser composto na primeira pessoa do singular, pois cada um falará de suas próprias ideias. Evitem generalizações indevidas (por exemplo, "o professor deve fazer..."), e falem de suas próprias perspectivas (por exemplo, "eu faria..." ou "eu farei..."), explicando sempre o porquê.

Sobre os conceitos, estes foram os conceitos centrais que cobrimos:

- Tecnologia

- Mídia(s)

- Letramento(s)

- Inclusão digital

- Cultura digital e cibercultura

- Nativos digitais 
- Metodologias ativas: dentre essas, a "sala de aula invertida" foi a abordagem central do curso (conforme estava planejado para o presencial, combinada com a "aprendizagem entre pares", que não efetivamos on-line).

Em termos de práticas e técnicas, vimos os seguintes:

\section{- Brainstorming ou chuva de ideias}

\section{- Mapeamento mental}

- Estudo dirigido: concebido de uma forma mais ampla do que o tradicional "ler e fazer fichamento/resumo"

- Webquest: eu não havia dado "nome aos bois" até agora, mas as atividades que vocês fizeram que envolveram buscas e leitura crítica de material na Web podem ser denominadas de Webquests. São um tipo amplo de metodologia que integra o uso da internet no ensinoaprendizagem. Nas atividades que vocês conduziram, adaptei a metodologia inserindo textos acadêmicos como base (os verbetes e o artigo sobre "nativos digitais") e dei diretrizes para as buscas. Isso pode ser feito de muitas formas diferentes, adaptadas às possibilidades e limites do segmento da educação em questão, com as diretrizes menos ou mais fechadas; por exemplo, no Ensino Médio vocês poderiam determinar os recursos (sites e até textos específicos) a serem usados, mas o que fiz aqui foi integrar um trabalho de letramento midiático mais amplo.

\section{Os recursos}

Como segunda parte, complementar à carta, vocês precisam apresentar exemplos de mídias ou recursos midiáticos que ilustrem as ideias principais do seu texto.

Aqui, a ideia é que vocês produzam ou selecionem entre 1 e 3 recursos que utilizariam para ilustrar sua abordagem e suas práticas. Podem discutir com colegas, se possível, mas cada um terá que apresentar suas próprias escolhas e/ou criações. 0 arquivo pdf disponibilizado no Bloco da Semana 14 será importante, mas vocês não precisam se restringir à minha lista - podem trazer outros apps, plataformas etc. que conheçam. O principal é que expliquem, no texto, como e porque utilizariam a(s) mídia(s) que escolherem.

Vou detalhar mais abaixo as opções dentro de três tipos gerais de suportes midiáticos, mas precisarão consultar o pdf com a lista para uma complementação dessas orientações (que também discutiremos no Zoom).

\section{Cada um deve escolher uma destas três possibilidades:}

- Imagens (3 imagens de, pelo menos, dois tipos diferentes): fotos, desenhos, mapas mentais, memes, tirinhas ou nuvens de palavras. Podem criar seu próprio material ou escolher da Web. A imagem no final da postagem é uma nuvem de palavras que fiz jogando o texto do artigo que vocês leram sobre "nativos digitais" na plataforma Tagcrowd (está na lista). O que a plataforma faz é analisar o texto para identificar as palavras mais usadas; a partir da contagem de quantas vezes elas aparecem, é criada uma figura que mostra a frequência relativa das palavras (quanto maior a fonte, mais frequente é a palavra no texto analisado).

- Vídeo (de até 1 minuto e meio de duração) feito ou selecionado ou editado por vocês: vídeos podem ser gravados e editados no celular e diretamente em sites (sem baixar app nenhum), e um tipo de vídeo conhecido como slideshow (apresentação de slides) pode ser criado no próprio PowerPoint (no computador, apenas - o Google Drive não tem essa funcionalidade), a partir de slides e gravação de voz e/ou colocação de trilha sonora). 
- Exemplo de app e/ou site (1 exemplo) que possa ser incorporado em práticas em sala de aula. Há muitos apps (para celular e para computador) e sites com joguinhos (e sites para montar joguinhos também) e também com material específico para matérias diferentes (por exemplo, a plataforma Educopedia, da SME, tem muitos materiais já prontos para quem quiser e puder, investigar - está na lista). Aqui também entram como possibilidades redes sociais (Facebook, Instagram etc.) e blogs.

Importante: notem que não estou fechando detalhes do cenário (por exemplo, professor de quê? Qual(is) ano(s)?) - isso fica para cada um decidir! O pessoal das Licenciaturas pode pensar em suas respectivas disciplinas específicas.

\section{Critérios e pontuação}

1) Mídias (selecionadas ou criadas): 2 pontos pela seleção ou entrega (no caso de mídias produzidas por vocês mesmos)

2) Texto reflexivo: 5 pontos divididos da seguinte forma:

- 0,5 ponto para formatação

- 0,5 ponto para qualidade da escrita (coesão, coerência e clareza)

- 1 ponto para a integração de uma boa explicação para a escolha das mídias apresentadas como ilustração

- 3 pontos para articulação de conceitos (lembrando: precisarão incluir 3)

\section{Entrega do material}

O trabalho deve ser colocado no próprio AVA que usamos ao longo do semestre. Vocês devem colocar todo o material em um único arquivo (imagens e links), e, se optarem por criarem vídeos, armazenem o vídeo em algum outro lugar (por exemplo, Google Drive) e incluam um link no arquivo que submeterem (não esqueçam de permitir o acesso via link, para que eu possa ver o vídeo, se for o caso).

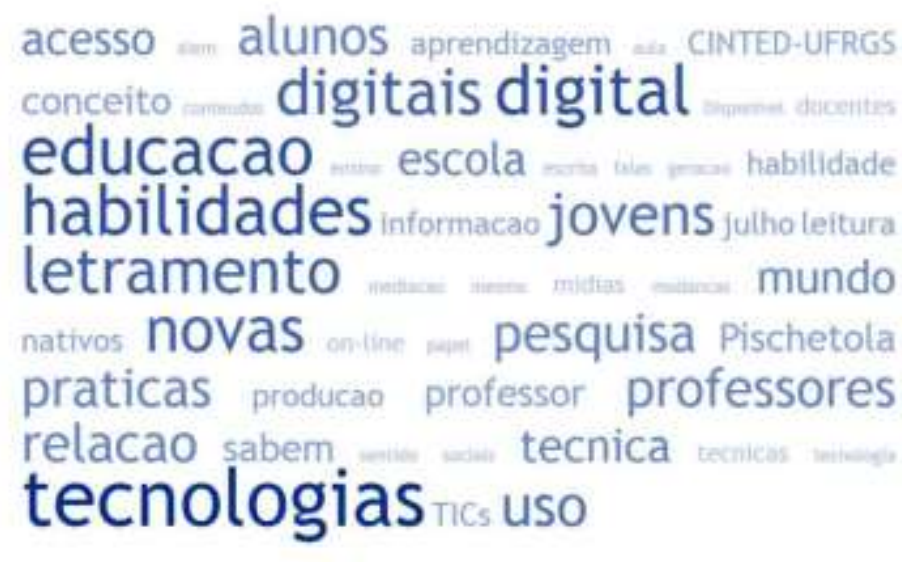

Nuvem de palavras de Pischetola; Heinsfeld (2018)

BOM TRABALHO!! 
APÊNDICE C - FICHA DE AVALIAÇÃO FINAL DE DISCIPLINA

DISCIPLINA - SEMESTRE - Profa Giselle M. S. Ferreira - DATA

Seu nome (opcional):

\section{AVALIAÇÃO}

Este é um momento importante para você, para mim e para a próxima oferta da disciplina. Obrigada por preencher os campos a seguir!

\section{1) (AUTOAVALIAÇÃO) COMO VOCÊ AVALIA:}
a) sua participação nas aulas?
b) a realização das atividades propostas?

Que nota daria para si (de 1 a 10, considerando 10 como excelente)?

\section{2) (AVALIAÇÃO DO CURSO) COMO VOCÊ AVALIA:}
a) as aulas?
b) os recursos utilizados (bibliografia, audiovisual, slides etc.)?
c) o uso do Google Drive para compartilhamento e envio de materiais?
c) a dinâmica das aulas?
d) a atuação da professora?

\section{3) COMENTÁRIOS GERAIS:}

"O texto traça uma genealogia do termo "ciberespaço" a partir de documentos e textos seminais da área dos Estudos da Internet. Recomendo, também, a recém-lançada coletânea completa, que congrega textos que discutem e atualizam ideias fundamentais ao pensamento educacional, partindo de três eixos teóricos basais: mente e cognição, materialidade e metáforas.

ii Estudo empírico recente sobre a questão da exaustão cognitiva associada ao excesso de videoconferência.

iii O texto explora um recorte dos dados produzidos em uma pesquisa sobre a utilização de APA com jovens no ensino médio integrado.

iv Este artigo discute a metáfora mais comumente utilizada para conceber as tecnologias na educação: as tecnologias como ferramentas.

${ }^{\vee}$ Este livro é um clássico da literatura sobre a EaD, escrito por um de seus pioneiros.

vi O artigo discute algumas metáforas comuns da tecnologia educacional e suas implicações para a educação. 
vii Dicionário de termos e conceitos da Educação e Tecnologia e da EaD, com verbetes escritos por mais de 200 especialistas.

viii O livro explora a noção de solucionismo tecnológico a partir de exemplos de tecnologias específicas e seu impacto social. Alguns exemplos remetem à educação, mas não é um livro focalizado neste setor.

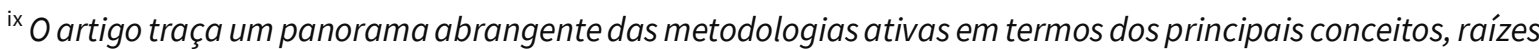
histórias e seus desdobramentos.

${ }^{x}$ Em minha opinião, esse livro é um excelente ponto de partida para explorar a produção acadêmica na área dos Estudos Críticos da Educação e Tecnologia. Uma tradução minha para o português do segundo capítulo pode ser encontrada no seguinte link:

https://ticpe.files.wordpress.com/2016/12/neil_selwyn_distrusting_cap2_trad_pt_final.pdf. Acesso em: 22 abr. 2021.

${ }^{x i}$ Neste capítulo, Selwyn parte de sete questões propostas por Neil Postman, crítico das mídias, para discutir o atual contexto da tecnologia educacional.

xii Este capítulo oferece uma discussão acerca dos conceitos de presença e distância na educação on-line a partir de uma perspectiva filosófica.

xiii Trata-se de um livro sobre a história desta universidade pioneira e inteiramente a distância.

xiv Neste livro, o autor discute, com uma ampla gama de exemplos, os últimos 25 anos de história da tecnologia educacional, sobretudo na Educação Aberta a Distância (EAD).

xv The Digital Scholar discute as transformações que estão a ocorrer nos processos envolvidos na vida acadêmica a partir da expansão da infraestrutura tecnológica digital. 